\title{
Determinants of Unequal Access to and Quality of Education in Indonesia
}

\author{
Tatang Muttaqin ${ }^{1}$ \\ Ministry of National Development Planning/BAPPENAS
}

\begin{abstract}
Indonesian government simultaneously improves access to and quality of education for all citizens. Although its efforts had noticeable impact, many of the targets to improve access to and quality of education nevertheless still have not been achieved and education inequality is still persistent. Using a multilevel multi-resource framework, this article comprehend some of the mechanisms behind the unequal access to and quality of education. It suggests that the impact of and interplays between human, social, economic, political and infrastructural capital at the individual, household, school, community and government level are important on inequality in access to and quality of education in Indonesia. For instance, family factors, such as wealth, education investment and educational background also reduce the likelihood that children are out of school; reciprocity can compensate low-income families for sending their children to preschool as a within level cross resource effect; living in a higher trust strengthen the effect of association on preschool participation as a between level single resource effect; residing in urban area reinforces the effect of associations but it weaken the effect of reciprocity on preschool participation as a between level cross resource effect consists in urbanization. In terms of decentralization, the length of schooling slightly increased but progress in the length of schooling slightly decreased after decentralization; even though student achievement and achievement gaps are strongly determined by student and family characteristics, the results show that differences between school tracks and streams also play an important role.
\end{abstract}

Keywords: Inequality, access, quality, education, multilevel, multiresource, Indonesia

\footnotetext{
1 Tatang Muttaqin is Head of Subdirectorate for Higher Education at the Ministry of National Development Planning/Bappenas and pursued $\mathrm{PhD}$ at the Department of Sociology/Interuniversity Center for Social Science Theory and Methodology (ICS), University of Groningen, the Netherlands.
} 
Determinants of Unequal Access to and Quality of Education in Indonesia

\section{Introduction}

On 11 June 2014, a story was published on the official Semarang State University (Unnes) website $^{2}$ reporting of a moment of inspiration concerning a young Indonesian woman, in a black gown and cap, who rode to her graduation ceremony in a rickshaw pushed by her father. Raeni (21 years), the daughter of Mugiono (55 years), a rickshaw driver, became the most popular university graduate of about 5 million university students in Indonesia that year. Raeni grew up in a poor family in Kendal, Central Java, and after graduating from vocational school, she was accepted in Semarang State University (Unnes) and received a scholarship from the Ministry of Education as recognition of her scholastic achievements. She finished her degree in accounting education with an almost perfect grade point of 3.96 out of 4.0 .

This story spread massively in both print and electronic mass media and caught the attention of President Susilo Bambang Yudhoyono, who invited Raeni and her father to meet him and his wife at the State Palace in Jakarta, where they presented her with a presidential scholarship for continuing her study in the United Kingdom. Why is Raeni's story so inspiring and why did it spread across country? Because her story represents an exception in an education system in which the poor, no matter how academically talented, have little or no chance of advancing to university. Often, the poor do not even continue to public high school, which is highly competitive, and most of them have already dropped out after elementary school or even never set foot in a school.

Raeni's story shows the importance of equal opportunities concerning access to and quality of education in Indonesia. Access to education impacts an individual's life because it has the potential to improve the ability to think critically, to solve problems and to make appropriate decisions (UNICEF, 2015). But for education to have these effects, it needs to be of good quality. Therefore, governments often seek to simultaneously improve access to and quality of education for all citizens. The Indonesian government is no exception. Although its efforts had noticeable impact, many of the targets to improve access to and quality of education nevertheless still have not been reached (Lundine et al., 2013).

The remainder of this introduction will give a short overview of these efforts and the sometimes contradictory scientific evidence about their effectiveness. This leads to the formulation of the research questions of the four propositions in this article.

\section{Government efforts to improve access to and quality of education}

The formal school system in Indonesia comprises of primary to higher education levels. The combination of 6 years primary school (grades 1-6) and 3 years junior secondary school (grades 7-9) results in 9 years compulsory basic education. After completing basic education, students continue to 3 years senior secondary school (grades 10-12) and higher education. However, before enrolling in primary school, some children attend formal or nonformal preschools. Formal schools, such as kindergartens (Taman Kanak-Kanak/Raudhatul Atfhal), concentrate on learning and have structured ways of teaching, whereas non-formal preschools, such as play groups (Kelompok Bermain), emphasize learning through playing (Yuniarti \& Hakim, 2014; Hasan et al., 2013). There are several governmental programs that focus on reducing disparity in access to and quality of education in Indonesia. 


\section{Expanding access to preschool}

To improve the access of poor children to preschools, the government has implemented the early childhood education and development project (ECED). This project ran from 2006 to 2012 and covered 738,000 children from 6,000 poor communities situated in 3,000 villages (Pradhan et al., 2013). It aimed to enhance poor children's development and their readiness for entering primary school. Three main interventions were used: (1) training for facilitators to promote community awareness regarding the importance of preschools and to learn to prepare proposals for financial subsidy (block grants); (2) subsidies to establish two centers (preschools) with about $\$ 18,000$ per village; (3) training two preschool teachers per center (Hasan et al., 2013). To complement the program at the village-level, the government also financed the national program for community empowerment (Program Nasional Pemberdayaan Masyarakat, PNPM). This program provides incentives to communities exceeding certain preschool enrollment thresholds. This government effort contributed to increase preschool participation of children in the age of 4 and 5 years from 30 percent in 2005 (CBS, 2005) to 51 percent in 2012 (World Bank, 2015).

\section{Universal education}

The constitution of Indonesia states that every citizen shall have the fundamental right to obtain education. But it was only in 1973, when national income increased through the oil boom, that the government started to take measures in this direction (Presidential Instruction No. 10/1973 on the Primary School Construction Program, INPRES SD). A program was designed to make sure that all children in the age of 7 to 12 years have access to school, particularly in rural, transmigration, new settlement and disadvantaged urban areas. This endeavor dramatically improved the enrolment rate of primary school and junior secondary school students from 41 percent and 17 percent in 1968 to respectively 99 percent and 47 percent in 1988 (Attachment to President's speech, 1993). In 1984, the government launched a six-year compulsory education policy. This was followed, in 1994, by the introduction of a nine-year compulsory education system (Arina, 2011). In July 2005, the government introduced a Free Basic Education program (FBE) (Paqueo \& Sparrow, 2005), and started providing a school assistance fund (Bantuan Operasional Sekolah, BOS) for children in primary and junior secondary education (MoEC, 2009). In 2013, the government began extending universal education from nine years to 12 years (MoEC, 2013). However, since 2006, there has been little progress in reducing the number of children who are out of school (CBS, 2011). Furthermore, there is only a slight decrease in the percentage of children who leave school before reaching the last grade of their nine-year compulsory education.

\section{Targeting the poor}

The government took four measures to improve school access and educational attainment of children from low-income households. First, in order to buffer the hardship resulting from the economic crisis that began in 1997, the government implemented a social safety net (SSN) program to maintain school enrolment rates and transition rates, to reduce dropout rates and to maintain the quality of the teaching and learning process. The SSN program consists of a scholarship for the poor and a school subsidy (Sparrow, 2007; Sumarto et al., 2002). Second, the school operational assistance (BOS) program, introduced in 2005, provided subsidies for both public and private schools, helping them to maintain their quality of service despite rising prices of school supplies. This fund also helped the schools to pay teacher salaries and supplies when parents had difficulties in paying school fees. Third, to anticipate negative effects of reducing the fuel subsidy, in 2005, the government implemented an unconditional cash transfer program (bantuan langsung tunai/BLT). Two years later cash transfers became conditional and were restricted to the domains of health, nutrition and education (Tim Penyusun Pedoman Umum PKH, 2007). For instance, poor households with 
children in the age of six to 15 received cash if their children enrolled in primary or junior secondary schools with an attendance rate of at least 85 percent. Fourth, in 2014, the government introduced the Indonesia smart card (kartu Indonesia pintar/KIP). It covered about 24 million poor students, including students eligible for scholarships and others that cannot attend school because of financial issues. Recipients could withdraw funds from the card in the appointed bank outlets.

\section{Improving scores in the national examinations}

Since 1965, the Ministry of Education and Culture (MoEC) annually conducts national examinations (ujian nasional/UN) for junior and senior secondary levels to assess and standardize students' performance (Fatchiati, 2015; Afrianto, 2008). Since 2005, national examinations are held by the Board of National Standards of Education (Badan Standar Nasional Pendidikan, BSNP) via the provinces and sub-district education offices at the end of each school year (about April or May). The objectives of the national examination are: (1) mapping the competency and quality of Indonesian national education; (2) setting a basis for selection criteria for entrance to high education level; (3) a monitoring instrument to identify weak schools, so that special measures can be taken to improve their quality (MoEC decree 75/2009).

\section{Decentralizing the education system}

In 2001, the government also decentralized the education sector by increasing local government autonomy and by allocating more resources to the level of districts and cities to the education sector (Budget Statistics 2006-2012). This policy enables local governments to improve public services, particularly in the education sector, because it is stated in the constitution that governments are obliged to allocate a minimum of 20 percent of their budgets to the education sector. Additionally, more than 2.6 million public servants were transferred from the management of the central government (MoEC) to the municipalities and schools. More than three quarters of these public servants are teachers (World Bank, 2003).

\section{Persistent gaps in quality of and access to education in Indonesia}

Even though the Indonesian government has made various efforts to reach the target of universal education, the objectives of increasing both access to and quality of education, while at the same time reducing inequalities, are far from accomplished. First, inequality still is a problem. In the age cohort from 13 to 15 years, 96 percent of students from wealthy households finish their education in 7 years. This figure drops to 80 percent for students from poor households (CBS, 2016, calculated by Bappenas). Second, with regard to access, there are still more than half a million children in the age of 7 to 15 years who had never set foot in a school in their entire life, and more than 1,7 million children in total left school before completing their nine-year compulsory education (CBS, 2011). Third, in terms of competence, 55 percent of Indonesian students' scores below average scores according to the Programme for International Student Assessment (PISA), 43 percent scores average, and only 2 percent scores above average (OECD, 2012; World Bank, 2014). Fourth, as far as quality is concerned, national exam scores of students in private schools are still lower than those of their peers in public schools (Newhouse \& Beegle, 2006), and there are also large variations within and between Islamic private schools.

Identifying appropriate policies to mitigate these problems requires insight into the potential antecedents behind variations in access and quality of education (MoEC, 2015). A large body of studies has pinpointed a wide range of such antecedents, including differences in school ownership (public and private), regional differences, and differences in the socioeconomic status of families (Al-Samarrai, 2013; Suharti, 2013; Suryadarma, 2010; Newhouse $\&$ Beegle, 2006). In addition, the transformation of Indonesia's political and administrative system, especially after the decentralization, also was found to play a role, although previous studies yielded contradicting results. On the one hand, decentralization improved educational outcomes, such as mean years of schooling, literacy rates and low high school dropout rates 
(e.g. Simatupang, 2009; Usman, 2001). On the other hand, it increased school costs and school dropout (cf. Kristiansen \& Pratikno, 2006).

The above scholarship shows the multifaceted and complex interrelationship between educational attainment and inequality. Their interplay is not only related to individual factors, such as gender, but also to human capital (parental education and occupation), economic capital, social capital and government interventions at various levels. For example, one could wonder how household and village social capital - an understudied topic in the Indonesian context - links to preschool enrollment. At the national level an important question is how political capital and the transfer of resources and authority to the local level affect inequality in educational attainment. A better understanding of the interplay between this large range of resource inequalities at different administrative levels, in turn, is pivotal for finding effective policy solutions (Lynch and Baker, 2005).

This paper aims to provide answers to these yet unanswered questions by disentangling the complex and multifaceted phenomenon of inequality in access and quality of education in Indonesia. The central research question of this paper therefore reads: To what extent and how do individual, household, school, community and government level characteristics, in particular variation in resources, influence unequal access to and quality of education in Indonesia?

\section{A multilevel and multi-resource framework}

Education inequality can be measured by diverse dimensions, such as access to education, student performance, and earning in later life (see e.g. Breen, et al., 2009; Pfeffer, 2008; Blau \& Kahn, 2005; Shavit \& Blossfeld, 1993). This book focuses on inequalities in educational access and student achievement. Access is measured by preschool and school enrollment (or dropout), and mean years of schooling. Student test scores are used as a measure for achievement.

Since the allocation of resources is one of the major tools a government has to affect educational outcomes, a resource perspective provides the point of departure for the analyses in this book. Resource or opportunity based explanations have successfully informed research in a variety of domains, including the educational sector. What is considered a "resource" differs between the approaches. In general, the Opportunity Structure Approach (Roberts, 2009; Merton, 1968) in sociology and the Resource Based View (Wernerfelt, 1984) in organization research use a very broad definition of resources. For example, the latter conceives resources as "all assets, capabilities, organizational processes, firm attributes, information, knowledge, etc. controlled by a firm" (Barney, 1991: 101). This definition includes a bundle of tangible and intangible assets, such as management skills, organizational processes, information and knowledge. In contrast, the Education Production Function Approach (Hanushek, 2007) focuses on student achievement as a function of the school's investments in activities and resources related to teaching, like time for instruction. Similarly, more specific frameworks, like Human Capital (Becker, 1993) or Social Capital Theories (e.g. Mladovsky, 2014; Song \& Lin, 2009; Beard, 2005) focus on a narrower set of resources.

The studies reported in this article follow this lead. More specifically, it explores how educational outcomes are related to investments and endowments in five broad categories of resources. These different types of resources are distributed across multiple societal levels. In our study, six of these levels are distinguished (the individual student, his or her household, the school, the village, the municipality and the national level).

First, human capital refers to the characteristics of a student's parents, such as parental education and occupation. In terms of occupational status, we consider whether a parent has a high-status job (such as being a civil servant, a lawyer or a doctor), or whether one has a low-status occupations (i.e. a farmer and a worker). For our analyses, we use aggregated information about human capital in the household, school, and municipality.

Second, the types of economic capital differ across levels of analysis. At the level of the household, key indicators are income, education expenditure and the poverty status of parents. At the school level, the level of economic capital is inferred from variations in investments into the quality and intensity of the primary process of teaching, like the selection and training of teachers. At the level of the village, we conceive average wealth from the average household expenditure per capita adjusted by the municipal-level poverty rate. At municipal-level, we 
include average wealth, government education expenditure, average household education, poverty rate and fiscal capacity as indicators of economic capital.

Third, social capital reflects the structure of relations that facilitate individuals to share information, strengthen reciprocity and foster trust. We use social capital indicators at the level of the household and at the level of the village. Household level social capital consists of: (1) association that facilitates the diffusion of information and may result in adopting behaviour of others; (2) trust in institutions and other people in the community; and (3) reciprocity as indicated by the easiness to borrow or lend money from others for emergency needs. In order to assess variations in village level social capital, we aggregate information on household social capital.

Fourth, we refer to investments into infrastructures, like accessibility of schools and access to mass media, as the infrastructural capital at the level of the household, village and the municipality. The distance to travel to school can hinder school accessibility. Therefore, children have to make great efforts to get to school, particularly in rural and remote areas with poor transportation infrastructures. In addition, though the government has increased access to radio and television as a way to promote (ideological) unity and exert government influence (power) in peripheral areas, there are also still remote areas that cannot be reached by mass media. To assess variations in access to mass media at village level, we aggregate data on household access to mass media.

Finally, we analyze the decentralization induced changes in political capital as the shift of authority, responsibilities, financial and human resources to the municipal level. This includes the implementation of direct elections of regents and mayors, and the creation of new municipalities. Table 1 gives an overview of the different types of capital and levels of analysis studied in this study.

Table 1. Resources based view across levels and contextual factors

\begin{tabular}{|c|c|c|c|c|c|}
\hline $\begin{array}{l}\text { Capital } \\
\text { Level }\end{array}$ & Economic & Human & Social & Infrastructure & Political \\
\hline National & & & & & $\begin{array}{l}\text { Policy to decentral- } \\
\text { ize education }\end{array}$ \\
\hline Municipal & $\begin{array}{l}\text { Wealth; mean } \\
\text { of household } \\
\text { education } \\
\text { expenditure; } \\
\text { public education } \\
\text { expenditure; pov- } \\
\text { erty rate; fiscal } \\
\text { capacity. }\end{array}$ & $\begin{array}{l}\text { Proportion of } \\
\text { parent from a } \\
\text { senior/higher } \\
\text { education } \\
\text { background; } \\
\text { Proportion of } \\
\text { parents with } \\
\text { a high-status } \\
\text { occupation. }\end{array}$ & $\begin{array}{l}\text { Type \& level of } \\
\text { development; } \\
\text { urbanization. }\end{array}$ & $\begin{array}{l}\text { Number of } \\
\text { schools. }\end{array}$ & $\begin{array}{l}\text { Newly created } \\
\text { municipalities. }\end{array}$ \\
\hline Village & Mean of wealth & & $\begin{array}{l}\text { Association; } \\
\text { trust; reciproci- } \\
\text { ty; urbanization. }\end{array}$ & $\begin{array}{l}\text { School availabil- } \\
\text { ity; access to } \\
\text { mass-media. }\end{array}$ & \\
\hline School & $\begin{array}{l}\text { Investments in } \\
\text { teaching time, } \\
\text { teacher selec- } \\
\text { tion, financial } \\
\text { support to } \\
\text { students. }\end{array}$ & $\begin{array}{l}\text { Proportion of } \\
\text { parents with a } \\
\text { senior/higher } \\
\text { education } \\
\text { background; } \\
\text { Proportion of } \\
\text { parents with } \\
\text { a high-status } \\
\text { occupation. } \\
\text { Investments in } \\
\text { teacher training }\end{array}$ & & & \\
\hline Household & $\begin{array}{l}\text { Expenditure per } \\
\text { capita, education } \\
\text { expenditure; } \\
\text { poverty status. }\end{array}$ & $\begin{array}{l}\text { Head of house- } \\
\text { hold education } \\
\text { background; } \\
\text { parental educa- } \\
\text { tion. }\end{array}$ & $\begin{array}{l}\text { Association; } \\
\text { trust; reciproc- } \\
\text { ity. }\end{array}$ & $\begin{array}{l}\text { Access to } \\
\text { mass-media. }\end{array}$ & \\
\hline
\end{tabular}


This multilevel multi-resource framework allows to systematically address one of the most pressing policy issues related to educational attainment: to what degree can a specific kind of resource deficiency that hampers access to and quality of education be compensated by access to resources of another type or from another level?

Three types of interplay can be distinguished. The first refers to within level cross resource effects. For example, if a lack of household economic capital may inhibit enrolling kids at school, can household social capital compensate for this lack of resources? The second refers to between level single resource effects. For example, under which conditions might school or municipality level economic capital offset a lack of economic resources at the household level? Finally, there are between levels cross resource effects. For example, to what degree may a low degree of human capital at the household level be compensated by school level economic capital like investments in teacher education? The four studies in this book explore a large variety of these effects.

Although much progress has been made in understanding the combined effects of various resource investments in education (e.g. Suharti, 2013; Saraswati, 2012; Newhouse \& Beegle, 2006), it is still unclear how the interplay between resource investments at household, village, school, and municipality-level jointly affect variations in educational outcomes in the context of decentralization of the Indonesian public sector.

Policy makers could opt to intervene in almost all levels in an attempt to reduce inequalities in education. Utilizing a resource-based approach, this study provides a comprehensive picture for policy makers to identify what kind of resources at which level might be needed to reduce educational inequality, and what type of stakeholders are involved and needed to contribute to government efforts to narrow this inequality.

\section{Applying the framework}

This article investigates the impact of differences in resources (at the individual, household, school, village and municipality-level) on four aspects of access to and/or quality of education: 1) Children dropping out of school or never attending school; 2) Preschool participation; 3) School participation and length of schooling; 4) Student achievement and achievement gaps. Figure 1 provides a conceptual model of the four studies.

Figure 1. Visual summary of research elements in paper

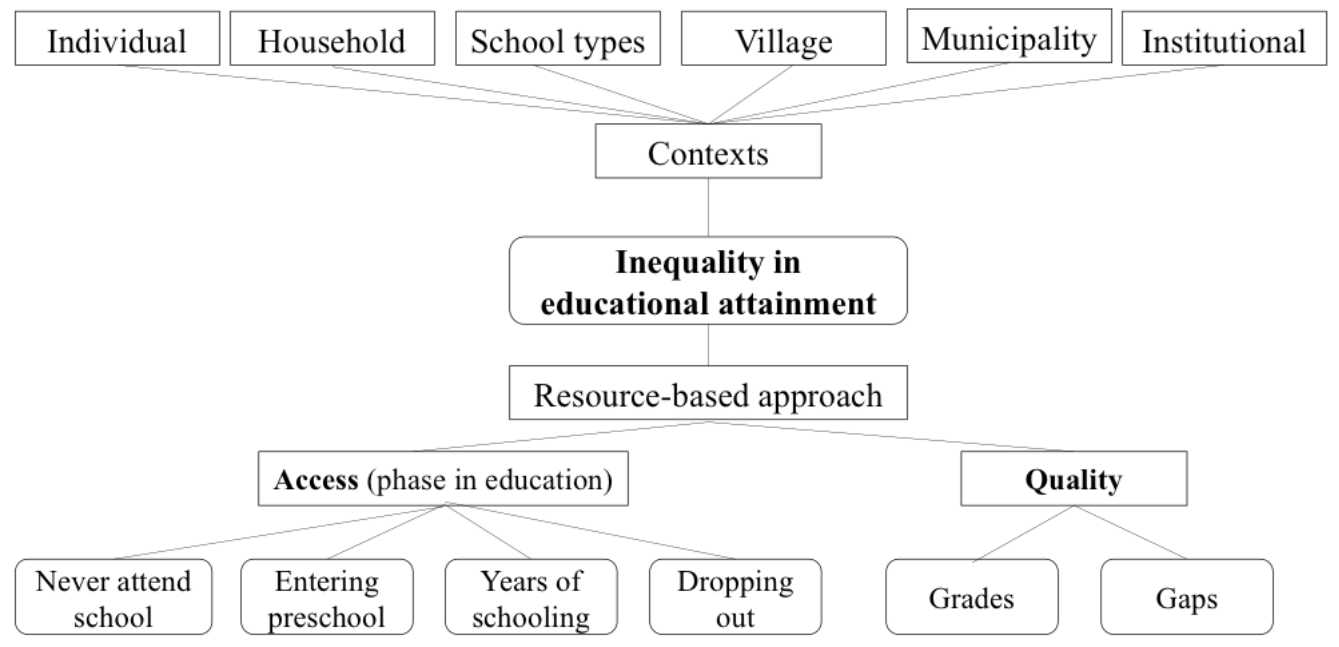

Being out of school: municipality and household level antecedents

Unlike in developed countries, lack of money for education at the household level is still a salient factor in developing countries. Many factors can stimulate or hamper school enrollment. On the one hand, governments could commit resources to provide free education 
for low-income children to address this issue. The Indonesian decentralized education system depends heavily on municipalities (districts and cities as the autonomous local governments) that have the authority and resources to manage primary and secondary education services that could explain why some children are in school and others not (Colclough et al., 2000).

On the other hand, economic revival can create temporary job market opportunities that may result in students dropping out of school (Gangl 2002; Allensworth 2005). Also accessibility problems as they may result from physical disability or living in remote areas could also be obstacles that cause large groups of children to never attend school (Shindler, 2010; Arunatilake, 2006). Last but not least, household resources and characteristics will also influence children's opportunities to attend school (Rumberger \& Larson, 1998; McNeal, 1999; Pong \& Ju, 2000).

An underexplored question in previous studies is to what degree municipality and household resources contribute to decrease the number of children never attending or dropping-out from school. Therefore the first sub-question of this paper is: Which characteristics at the level of municipalities, households and children help to explain why children never attend or drop out from school in Indonesia? Building on an opportunity structure approach (Roberts, 2009), it focuses on educational opportunities and constraints, particularly in terms of available resources at the municipal level (such as government education expenditure, poverty rate, mean of household education) and the household level (such as parental wealth and education, education expenditure and school availability near the house). This proposition enriches previous research on children that are out of school (Shahnaz \& Naeem, 2012; Suliman and El-Kogali, 2010; Shindler, 2010; Arunatilake, 2006) in three ways. First, it elucidates to what degree never attending school and dropping our of school are associated with the same antecedents (Shindler, 2010). Second, whereas previous studies have mainly focused on explanations based on characteristics of the individual, the family or the community (cf. Wenger, 2002; Rumberger, 2004; Allensworth, 2005; Anderson, 2010), this chapter also incorporates municipality factors. Third, the application of multilevel analysis allows us to examine cross level multiple resource effects on both dropping out and never attending school.

\section{Preschool participation: household and community level antecedents}

Indonesia has low preschool participation rates (World Bank, 2015). Studies show that parental resources are crucial for preschool enrolment (Hasan et al., 2013; Self \& Grabowski, 2008; Alderman, 2006; Knight and Song, 2000). In developed countries, next to parental SES, social capital was found to improve enrolment rates (Smith et al., 1995; Teachman et al., 1996).

Indonesia has dense social networks and community organizations (Lasagni \& Lollo, 2011), which can buffer the lack of economic resources (White \& Kaufman, 1997) or may complement other forms of capital (Robison et al., 2002) which may cause the low preschool participation rate. For example, social capital may contribute to the effectiveness of policies aiming to enhance preschool enrolment through social and financial support. Nevertheless, little is known about the link between social capital and educational outcomes. Proposition 2 therefore addresses the second sub-question of this paper: To what extent and under which conditions can variations in preschool participation be explained by differences in householdlevel and community-level resources, and what is the moderating role of social capital?

By including the effects of social capital both at household and community-level, this chapter fills a gap in current scholarship on preschool participation in Indonesia, in which these aspects have so far received little attention (e.g. Hasan et al., 2013; Self \& Grabowski, 2008; Barnett \& Yarosz, 2007; Alderman, 2006). In addition to main effects of social capital, this chapter investigates the interplays between SES and social capital within the household level.

Furthermore, moderation analysis allows disentangling the potentially complementing and compensating effect of social capital. Complementing effects of social capital suggest to strengthen the effects of other resources (Song \& Lin, 2009). Compensation effects of social capital can buffer lack of other resources (Mladovsky, 2014). For instance, can social capital compensate low parental income and education? And, under which community conditions are 
the effects of social capital weakened or strengthened (i.e. cross-level interaction effects)?

\section{Educational attainment: provincial and municipal level antecedents}

With the decentralization of the educational system, local governments acquired a more central position in the allocation of political and financial resources to education services. However, there is disagreement about how decentralization may impact educational outcomes. On the one hand, decentralization enables the local government to properly respond to local demands to improve educational services (Simatupang, 2009; Heredia-Ortiz, 2007). Proponents of educational decentralization therefore predict rising enrollment rates, mean years of schooling, adult literacy rates, female literacy rates, and decreasing dropout rates (Simatupang, 2009; Galiani \& Schargrodsky, 2002; Habibi et al., 2001). Conversely, opponents predict a negative impact on educational outcomes and increasing school costs (Kristiansen \& Pratikno, 2006; Treisman, 2000). In an attempt to settle this issue, this study investigates under which conditions variations in local government resources relate to educational attainment. Part 3 therefore addresses the third sub-question of this study: To what extent did the decentralization of Indonesia's educational sector affect (variability in) educational attainment at the provincial and municipal levels?

This part of paper contributes to the existing literature on education in Indonesia by presenting the first "before and after analysis" of the impact of decentralization on regional variations in educational attainment. This study also provides insight of the effect of decentralization on regional inequality which may be helpful in developing tailor-made policy interventions aimed at reducing regional disparities in the Indonesian context.

\section{Student achievement: school level antecedents}

Differences in resources also affect the quality of education in terms student achievement, and they may lead to achievement gaps. Previous research emphasizes differences between public and private schools (e.g. Bernardo et al., 2015; Braun et al., 2006; Newhouse \& Beegle, 2006), but paid relatively little attention to differences between private schools, in particular between Islamic private schools. These differ considerably in terms of ideological orientation ("stream": modernist, traditionalist, integrationist) and organizational arrangements ("track": madrasah versus non madrasah schools). We argue that these ideological and organizational profiles reflect considerable differences in resource allocation decisions, i.e. the degree to which investments are made into the primary process, like teacher selection and training. We expect these differences to affect student achievement. Proposition 3 therefore asks: How can variations in the (gender and parental socio-economic status related gaps of) academic achievement of students attending private Islamic schools be explained by ideological and organizational differences of their schools?

Using an education production function approach (Hanushek, 2007), this proposition argues that schools investing more into the primary process of teaching (e.g. through time investment, selection and training of teachers) will produce students with better outcomes on national exams. Additionally, this study examines achievement gaps by conducting interplays between level single resource effects and between levels cross resource effects.

Using interaction analyses, we expect that one resource can be complementary or compensatory (buffer) of the other resources. For instance, implementation of single sex education in the madrasah track and integrationist stream may reinforce the gender achievement gaps. In terms of the SES gap, financial support for low SES students via scholarships could improve attendance in the non-madrasah track and the Traditionalist and Modernist stream, which may reduce achievement gaps.

\section{Research design and data}

We use and combine various nation-wide surveys and administrative datasets from five different sources: (1) Central Bureau Statistics (CBS), (2) Ministry of Education and Culture (MoEC), (3) Ministry of Finance (MoF), (4) Ministry of Development for Disadvantaged Region (MDDR) and (5) Ministry of Home Affair (MoHA). In addition, we collected primary data from 
expert interviews with heads of Traditionalist, Modernist and Integrationist non-governmental umbrella organizations in Indonesia. In most propositions, we made combinations of various datasets in order to extract the required multilevel information necessary to answer our research questions with multilevel data analysis techniques. Below the main data sources are discussed.

\section{National social economic survey (Susenas 1996-1999 and 2008-2011)}

Several propositions make use of the rich dataset provided by the national social economic survey (Susenas), conducted by the Indonesian Central Bureau of Statistics (CBS). This survey monitors key indicators of social and economic development in Indonesia. It started in 1963 with 16,000 households in the sample. During 1963-1978, it was conducted every two years (the Core). Since 1992 the core module is collected annually. Modules on special topics are added every three years. In 2011, the Susenas covered 285,307 households, which comprised 1,118,239 individuals (CBS, 2011). The annual Core covers eight indices: demography, health, education, labor, fertility and family planning, housing, and consumption. The Module is divided in three clusters: (1) social, culture and education; (2) housing and health; (3) household consumption and expenditure (CBS 2013). The survey initially uses a stratified multi-stage cluster sampling with two strata (urban and rural) for each municipality. Then, it follows a two-stage cluster sampling strategy for urban areas by dividing them into census blocks (CBs) and then to select a number of CBs using linear systematic sampling. In rural areas, a number of sub-districts are sampled using probability proportional to size of population. For each selected $C B$, sixteen households are selected to be interviewed by using linear systematic sampling (CBS, 2011; Hull, 2013). We used the Susenas data to examine the effects of various forms of capital on education inequality, such as human capital (parental education and occupation) and economic capital (education expenditure and poverty status of parents) at the household and municipal level, and social capital (association, trust and reciprocity) at the household and village level.

\section{Village potential (Podes, 2011)}

Since 1980, the CBS also compiles the so-called Village Potential (Podes) dataset as part of the population census. In 2011, Podes covered 75.410 villages. It contains general information about villages, such as the village population, employment, housing and environment issues, education, health, socio-cultural aspects, transportation, communication, information, land usage, economy, security, village autonomy, community empowerment programs, village apparatus, agriculture, and supporting factors and obstacles (Hull, 2013). In terms of education, it covers information on the numbers of educational institutions, ranging from preschool to university, general and religious, and public and private schools/ universities. We use the Podes data to study the availability of schools in the village and to acquire information about school distance.

\section{National examination dataset (MoEC, 2013)}

National examination data is administered by the Education Assessment Centre of the Research and Development Board, which is part of the Ministry of Education and Culture (MoEC). The data covers the national exam scores of all three national exam subjects (Mathematics, Science, Indonesian and English) at the junior secondary school level. Along with the scores, the dataset provides information about the gender and age of the students, their parental education and occupation, school names and locations. In 2013, the dataset consisted of $3,671,863$ students nested in 48,962 schools, both public and private, and madrasah and non-madrasah. We used the data to investigate the effects of human capital and economic capital at household, school and municipal level on student achievement and achievement gaps in various tracks and streams in private Islamic schools. 
The Ministry of Finance (MoF), via the Directorate General of Regional Budgeting (MoF, 2013), offers electronic access to the local government expenditure (LGE) dataset. It covers local government expenditure data, classified into nine dimensions: (1) general services; (2) order and peace; (3) economy; (4) environment; (5) housing and service facilities; (6) health; (7) tourism and culture; (8) education; and (9) social protection. We used the LGE dataset to investigate the effect of municipality education expenditure on education inequality.

\section{Fiscal capacity index (MoF 2011)}

The requirement to report information of the local government's fiscal capacity originates from a decree of the Minister of Finance (MoF) No.244/PMK.07/2011. We used this fiscal capacity index to investigate the effect of municipality fiscal capacity on municipality educational attainment.

\section{Municipality development (MDDR 2011)}

The municipality development dataset refers to data on 183 underdeveloped municipalities. The MDDR was issued by the Ministry for the Development of Disadvantaged Regions (MDDR) in 2011. It defines underdeveloped municipalities on the basis of six criteria: economy, human development index, infrastructure, fiscal capacity, accessibility and other local characteristics. We merged the municipality development data of the MDDR with the Susenas dataset, and classified the municipalities in three types: city, developed district and underdeveloped district.

\section{Newly created municipalities (MoHA 2008-2011)}

Information of newly created municipalities was retrieved from the Ministry of Home Affairs (MoHA). Based on an updated list of the number of municipalities for 2008-2011, newly created municipalities could be identified. We used this data to examine whether there are differences between 'old' and 'new' municipalities and whether this affects municipality educational attainment.

\section{Expert interviews with heads of Traditionalist, Modernist, Integrationist organizations}

For the proposition on differences in resource investments in different tracks and streams in private Islamic schools, we interviewed the Vice Chairman of the Primary and Secondary Education Council of Muhammadiyah (Modernist), the Vice Chairman of LP Maarif NU (Traditionalist), and the Chairman of JSIT (Integrationist). These experts provided crucial background information about the streams' vision and mission and how the schools incorporate the national curriculum. In addition, the experts informed the researcher on the number of teaching hours, teacher training, teaching qualification, extra attention for specific subjects, investments in coordination, financial or other support for low SES pupils, and implementation of single sex classes. We also consulted these experts to crosscheck the schools' membership to one of the three streams and one of the two tracks. Table 2 provides a summary overview of the empirical propositions, research design and data. 
Table 2. Summary of the empirical propositions of the study

\begin{tabular}{|c|c|c|c|}
\hline Proposition & Research question & Dependent variable & Data source and design \\
\hline 1 & $\begin{array}{l}\text { Which characteristics at } \\
\text { the level of municipalities, } \\
\text { households and children help } \\
\text { to explain why children never } \\
\text { attend or drop out from school } \\
\text { in Indonesia? }\end{array}$ & $\begin{array}{l}\text { School enrolment: (1) never } \\
\text { attended school; (2) attend- } \\
\text { ing school; (3) drop-out. }\end{array}$ & $\begin{array}{l}\text { - National Socio-economic } \\
\text { Survey (NSS 2010). } \\
\text { - Village Potential (Podes, } \\
\text { 2011). } \\
\text { - Local government expen- } \\
\text { diture/LGE (MoF, 2013). } \\
\text { Multilevel multinomial } \\
\text { regression analysis. }\end{array}$ \\
\hline 2 & $\begin{array}{l}\text { To what extent and under } \\
\text { which conditions can varia- } \\
\text { tions in preschool participation } \\
\text { be explained by differences in } \\
\text { household- and community-lev- } \\
\text { el factors - such as SES, mod- } \\
\text { ernization and urbanization } \\
\text { - and what is the moderating } \\
\text { role of social capital? }\end{array}$ & Preschool enrollment. & $\begin{array}{l}\text { - National Socio-economic } \\
\text { Survey (NSS 2009). } \\
\text { - Village Potential (Podes, } \\
\text { 2011). } \\
\text { Multilevel logistic regres- } \\
\text { sion analyses. }\end{array}$ \\
\hline 3 & $\begin{array}{l}\text { To what extent did the de- } \\
\text { centralization of Indonesia's } \\
\text { educational sector affect } \\
\text { (variability in) educational at- } \\
\text { tainment at the provincial and } \\
\text { municipal levels? }\end{array}$ & Length of schooling. & $\begin{array}{l}\text { - National Socio-economic } \\
\text { Survey (NSS 1996-1999 } \\
\text { and 2008-2011). } \\
\text { - Municipality develop- } \\
\text { ment (MDDR 2011). } \\
\text { - Newly created municipal- } \\
\text { ities (MoHA 2008-2011). } \\
\text { - Fiscal capacity index } \\
\text { (MoF 2011). } \\
\text { Multilevel regression } \\
\text { analyses }\end{array}$ \\
\hline 4 & $\begin{array}{l}\text { How do various streams } \\
\text { and tracks in Islamic private } \\
\text { schools affect students' aca- } \\
\text { demic achievement and reduc- } \\
\text { ing achievement gaps across } \\
\text { gender and parental SES? }\end{array}$ & $\begin{array}{l}\text { National examination (NE) } \\
\text { scores of Mathematics, } \\
\text { Science, and English. }\end{array}$ & $\begin{array}{l}\text { - National examination } \\
\text { dataset (MoEC, 2013). } \\
\text { - National Socio-economic } \\
\text { Survey (NSS 2010). } \\
\\
\text { Multilevel regression } \\
\text { analyses. }\end{array}$ \\
\hline
\end{tabular}




\section{Contributions}

This paper theoretically contributes in at least three ways:

First, this paper is among the first to use a multilevel multi-resource framework to generate systematic quantitative evidence on the determinants of unequal access to and quality of education in Indonesia. This allows a more fine grained exploration of the complex interplay between different levels and different types of resources, and their effect on inequality in access to and quality of education. The propositions and findings concerning within level cross resource effects, between level single resource effects and between levels cross resource effects may also be useful in guiding future research on educational inequality in other countries.

Second, in terms of institutional change, this study is among the very few that tries to trace how Indonesia's "big bang" decentralization affects educational outcomes through time.

Finally, this study draws on an exceptionally large body of different large scale datasets from different sources. The combination of several of these datasets allowed us to achieve an exceptionally high degree of contextualization both with regard to a large number of levels of analysis and policy making (the individual, household, school, community, municipality and province), as with regard to a broad range of resources and capitals (economic, human, social, infrastructure, and political). This encompassing multilevel multi-resource framework provides researchers and policy makers with a more complete picture of the determinants of access to and quality of education in Indonesia. The findings of the studies, therefore, may assist policy makers to carefully think through policy and budget allocation decisions while attempting to further improve access to and the quality of education in Indonesia.

\section{Findings}

Inequality in access to and quality of education in developing countries, such as Indonesia, is to some degree inevitable for the initial stages of development (Kuznets in Galbraith, 2007). Nevertheless, high educational inequality creates moral questions, and can result in social divisions that reduce the efficiency of both government and society (Budihardjo, 2011; Kozol, 2005; De Gregorio, 2002). It is therefore considered an important sector for government intervention, also in developing countries.

There are no secret formulas for governments to design policies to mitigate education inequality, and Indonesia is no exception. For instance, since the 1970s, in order to reduce inequality in access to education, the government started to expand access to primary education. The idea behind this was to make sure that all children from the age of seven to twelve years old would have access to school, particularly in rural, new settlement and disadvantaged urban areas. In July 2005, in order to push towards universal primary and junior secondary education, the government introduced a Free Basic Education (FBE) (Paqueo \& Sparrow, 2005). However, despite these measures, education inequality is still pervasive in Indonesia, showing that it is not easy to address inequalities in this sector (CBS 2016 calculated by Bappenas; World Bank, 2014; OECD, 2012).

It is a common understanding that inequalities in Indonesia's education system are due to differences in resources related to family socio-economic status (SES), public and private school governance, and local government investments (Al-Samarrai, 2013; Suharti, 2013; Newhouse \& Beegle, 2006). However, inequality in access to and quality of education seems to be a more complex problem related to many factors across various levels and different types of resources (Lynch and Baker, 2005). So far, little systematic empirical research disentangles this complexity of multilevel and multi-resource determinants. This paper is among the first attempts to bridge this gap.

Building on a multi-level multi-resource approach and utilizing a combination of empirical nation-wide datasets by means of multilevel statistical techniques, this paper explored the impact of and interplays between human, social, economic, political and infrastructural capital at the individual, household, school, community and government level. In this way, and through the identification of within level cross resource effects, between level single resource effects and between level cross resource effects, this study provides deeper insights into which kind of resources contribute to reduce educational inequality, at which levels, and by means of 
what mechanisms. This may help stakeholders and the government to identify efforts needed to narrow this inequality in Indonesia. This concluding proposition summarizes the main findings of each proposition as follows:

Municipality and household resources' effect on the likelihood of children out-of-school

Proposition 12 explored the effect of municipality and household resources on the likelihood of children to be in or out of school. After the implementation of a decentralized education system in Indonesia, local governments have become crucial actors in providing access to education. Differences in municipality resources in these autonomous local governments may therefore influence the accessibility and affordability of schools. Accessible and affordable schools enable parents to send their children to school. Municipalities with more resources, for example, can provide more scholarships to households, which might attract poor pupils to attend or return to school. Also, differences in household resources, such as income, education investments, parents' educational level, household structure, and distance to school, are very crucial in parent's decisions on children's education. Furthermore, parent's wealth links to education investments and associates with the degree of awareness of the importance of education as a vehicle of social mobility. This awareness increases the importance parents attach to education, and therefore the price they are willing to pay.

Our analysis of the effect of differences in municipal and household level resources on the likelihood of children to be out of school showed that municipality education expenditure can help prevent dropout but it could not attract children to attend school to begin with. Conversely, the availability of schools decreases the likelihood that children never attend school but it does not reduce dropout. High municipality poverty rates increase the likelihood of children never attending school, but they also lead to lower dropout rates. Family factors, such as wealth, education investment and educational background also reduce the likelihood that children are out of school. We conclude that municipalities that combine the resources of good school availability and high(er) education expenditure seem to be better able to prevent that children drop out of or never attend school.

All in all, our analyses show that economic resources at both the municipal and household level affect the likelihood of children to be out of school differently, for different groups (i.e. children dropping out or never attending). Also, human capital at the household level contributes to the likelihood of children out of school, with children from less educated parents being more likely to never attend or drop out of school.

\section{The moderating role of social capital}

Proposition 2 examined to what extent socio-economic status (SES) and social capital affect preschool participation and whether social capital can compensate and complement these SES effects. High SES links to a household's spending capacity, high educational expectations, and to modernization and urbanization; elements that all are expected to affect preschool participation (Galab et al., 2013; Davis-Kean, 2005; McNeal, 1999). Next to SES, we argued that social capital could be an important determinant of educational outcomes. Social capital enables individuals and groups to achieve their objectives by sharing information and transferring values and norms. It also facilitates members of a group to cooperate. Social capital in this particular study resides in relations between individuals in families and communities who interact with others, both within the village and between villages. We identified three dimensions of social capital: association, trust and reciprocity and reasoned how these dimensions may influence children's preschool participation.

We found that parental income and education are strong determinants of preschool enrollment, whereas living in a poor rural area with lack of access to media is associated with declining preschool participation. Social capital represented by household association and community reciprocity increase preschool participation. Social capital based on perceived reciprocity compensates low-income parents that empower them to send their children to preschool.

In addition, we also found three interplay mechanisms: (1) one within level cross resource effect is that reciprocity, as a component of social capital at the household level, is able to compensate low-income families for sending their children to preschool; (2) a between level single resource effect is that the effect of association as a social resource at the household 
level on preschool participation becomes stronger if the household resides in an area with higher community trust, which is also a type of social resource; (3) a between level cross resource effect consists in urbanization reinforcing the effect of community associations, and weakening the effect of community reciprocity on the likelihood of children attending preschool. Overall, a combination of different types of resources, such as economic, human, social and infrastructural capital, in both household and village levels, contribute to preschool participation.

\section{Political resources' effect on the length of schooling}

Proposition 3 studied the effects of implementing a decentralized education system on the progress of and variations in the mean years of schooling between Indonesian municipalities and provinces. A decentralized education system is assumed to be good for education because it allows municipalities to raise more of their own resources, which is conducive to improve educational attainment.

Differences between municipalities, relating to voters' preferences but also decisionmaking and implementation capacity at the municipal level, may intensify regional variations in educational attainment. For example, decentralization may increase disparities in municipality education expenditures, which thus enlarges gaps in fiscal capacities for education across municipalities. Furthermore, differences in terms of urbanization, level of development and newly created municipalities may widen disparities, such as in infrastructure, facilities, and travel distances to school, which in turn can influence variations in educational attainment. Thus, decentralization generates differential effects on the improvement and progress of educational attainment between municipalities and between provinces.

We found that the decentralized education system as a political resource slightly improved the length of schooling. It also slightly decreased variation between provinces, but the variation among municipalities increased. Development and urbanization significantly improve the length of schooling. However, fiscal capacity and newly created municipalities do not have a significant effect on improving the length of schooling. It could be concluded that while municipal economic resources did not improve educational attainment at municipal level, urbanization, type and level of municipal development as a social resource significantly improved educational attainment.

\section{The effect of organizational and ideological resources on achievement gaps}

Finally, proposition 4 investigated whether ideological and organizational differences between Islamic private schools, and the resulting differences in resources and investment decisions, have consequences for educational achievement and gender and SES gaps in achievement. We reasoned that, compared to private madrasahs, private non-madrasahs have more resources: they devote more time to teaching, have more qualified teachers, and invest more in students, organization and coordination.

This difference in investments is assumed to significantly enhance student performance in non-madrasahs compared to their madrasah peers. In terms of ideological differences, the Integrationist stream devotes more teaching time by better teachers and more resources when compared to Traditionalist and Modernist streams. The Integrationist stream also provides extra attention to national exam subjects, which is expected to lead to higher academic achievement compared to the Modernist and Traditionalist streams. We found that student achievement in madrasahs is higher than in the non-madrasahs, and the achievement of girls is higher in the Integrationist stream.

In terms of the gender achievement gap, compared to non-madrasahs, madrasahs tend to be stricter and they are mainly practicing a tradition of single sex education (SSE). This is comparable with the Integrationist stream. Single sex education has been found to make girls freer and more competitive and to enable them to focus more on learning, leading to increased educational achievement. Single sex education is assumed to widen the gender gap to the benefit of girls. Our findings show that in the subject "Science", girls in the Integrationist stream and girls in madrasahs indeed perform better than their peers in other streams.

In terms of the SES achievement gap, non-madrasah schools have more resources: they 
can provide more financial support to low SES students to improve their achievement and reduce the SES gap. Unlike the Integrationist stream, Traditionalist and Modernist streams financially support low SES students, which may improve the performance of low SES students and reduce the SES achievement gap. Our analyses showed that, for English, the SES gap in private madrasahs is smaller than in their non-madrasah counterparts.

We found two interplay mechanisms. First, even though girls in general perform better than boys, between level and cross resource effects reveal that attending in Traditionalist and Modernist streams significantly decrease the achievement of female students. Second, compared to non-madrasah schools, madrasahs have less economic resources. Between level single resource effects show being located in a municipality with a high poverty rate diminishes madrasah's positive effect on student achievement. Overall, although student characteristics and economic and human capital at the household level strongly affect student achievement and achievement gaps, our findings suggest that differences in resource investment decisions across school tracks and streams also play an important role.

Table 3 summarizes the main theoretical mechanisms, outcomes and predictors, hypotheses and findings of each study.

Table 3. Summary of theoretical frameworks and findings of empirical proposition

\begin{tabular}{|c|c|c|}
\hline Mechanism & Description & Outcomes and Predictors \\
\hline $\begin{array}{l}\text { Proposition } 1 \\
\text { Opportunity and } \\
\text { constraint }\end{array}$ & $\begin{array}{l}\text { Resources at both municipality and household may } \\
\text { provide educational opportunities and constraints. At } \\
\text { the municipality-level, public education expenditure, } \\
\text { poverty rate and average household education } \\
\text { expenditure will explain why some children are in } \\
\text { school and others not. At the household-level, income, } \\
\text { education investments, parental educational, household } \\
\text { structure, and distance to school will also influence } \\
\text { children's opportunities to attend school. }\end{array}$ & $\begin{array}{l}\text { Outcome: Out-of-school } \\
\text { Predictors: Municipality and household } \\
\text { resources }\end{array}$ \\
\hline $\begin{array}{l}\text { Proposition } 1 \\
\text { Social capital theory }\end{array}$ & $\begin{array}{l}\text { Resources at household and community-level as } \\
\text { represented by SES and access to media may explain } \\
\text { preschool enrolment. Differences in social capital may } \\
\text { also play important role in parents decision on their } \\
\text { children preschool enrollment. Social capital can be } \\
\text { also an effective buffer against the negative effect of } \\
\text { lack of SES or it may complement other forms of } \\
\text { capital. }\end{array}$ & $\begin{array}{l}\text { Outcome: Preschool enrollment } \\
\text { Predictors: Household and community } \\
\text { resources. } \\
\text { Moderator: Social capital (association, } \\
\text { trust, reciprocity) }\end{array}$ \\
\hline $\begin{array}{l}\text { Proposition } 1 \\
\text { Decentralization }\end{array}$ & $\begin{array}{l}\text { Decentralization enables the local government to } \\
\text { respond to local demands, improve accountability and } \\
\text { effectiveness, which turn to increase length of } \\
\text { schooling. However, it could also have negative effects } \\
\text { if the lower administrative levels as a new actor in } \\
\text { educational service provision do not function well. } \\
\text { Thus, decentralization generate differential effects on } \\
\text { length of schooling in the various regional and local } \\
\text { levels. }\end{array}$ & $\begin{array}{l}\text { Outcome: Length of schooling } \\
\text { Predictors: Decentralization, fiscal } \\
\text { capacity, urbanization, level of } \\
\text { development, proliferation }\end{array}$ \\
\hline $\begin{array}{l}\text { Proposition } 1 \\
\text { Education production } \\
\text { function and } \\
\text { governance approach }\end{array}$ & $\begin{array}{l}\text { Ideological and organizational differences between } \\
\text { Islamic private schools have consequences for } \\
\text { investment and resource allocation decisions. These } \\
\text { variations in investments might explain variations in } \\
\text { student achievement and achievement gaps between the } \\
\text { various types of private Islamic schools in Indonesia. }\end{array}$ & $\begin{array}{l}\text { Outcomes: Student achievement and } \\
\text { achievement gap } \\
\text { Predictors: School tracks and streams } \\
\text { Moderators: Parent SES and gender }\end{array}$ \\
\hline
\end{tabular}




\section{Theoretical, Methodological and Practical Implications}

\section{Theoretical Implications}

A resource-based approach highlights the importance of the relation between various types of resources and educational outcomes and inequality (Al-Samarrai, 2013; Suryadarma, 2010; Hanushek, 2007; Newhouse and Beegle, 2006; Barro and Lee, 2001). Resources can originate in various levels, ranging from the individual to the government level. This study builds on and extends previous studies by using a multilevel multi-resources framework to systematically address the effects of differences in resources at various levels on educational attainment.

Our four studies suggest that various resources at the individual, household, community and government level explain inequality in education outcomes and show under which condition resource deficiency can be compensated by access to resources of another type or from another level. Table 6.2 summarizes the findings in this paper in terms of the interrelationship between economic, human, social, physical, and municipality resources and inequality of educational outcomes across level of individual, household, school, community and municipality.

Table 4. Summary of the effects of different types of resources across different levels

\begin{tabular}{|c|c|c|c|c|c|}
\hline $\begin{array}{c}\text { Capital } \rightleftharpoons \\
\text { Level }\end{array}$ & Economic & Human & Social & Infrastructure & Political \\
\hline National & & & & & $\begin{array}{l}\text { Policy to } \\
\text { decentralize } \\
\text { education } \\
\text { [Mixed] }\end{array}$ \\
\hline Municipal & $\begin{array}{c}\text { - Wealth [+] } \\
\text {-Household } \\
\text { education } \\
\text { expenditure [Mixed] } \\
\text { - Public education } \\
\text { expenditure [Mixed] } \\
\text { - Poverty rate [Mixed] } \\
\text { - Fiscal capacity [0] }\end{array}$ & $\begin{array}{l}\text {-Well-educated } \\
\text { parents [0] }\end{array}$ & $\begin{array}{l}- \text { Type and level of } \\
\text { development [+] } \\
\text { - Urbanization }[+]\end{array}$ & $\begin{array}{c}\text { - Number of } \\
\text { schools [Mixed] } \\
\text {-School availability } \\
{[\text { Mix] }}\end{array}$ & $\begin{array}{l}\text { - Newly created } \\
\text { municipalities [0] }\end{array}$ \\
\hline Village & - Mean of wealth & & $\begin{array}{c}\text {-Association [0] } \\
\text {-Trust [0] } \\
\text { - Reciprocity [+] } \\
\text { - Urbanization [+] }\end{array}$ & $\begin{array}{l}\text {-School availability } \\
{[+]} \\
\text { - Access to mass- } \\
\text { media [+] }\end{array}$ & \\
\hline School & $\begin{array}{l}\text { - Teaching time [+] } \\
\text { - Teacher selection } \\
\text { [Mixed] } \\
\text { - Financial support to } \\
\text { students [Mixed] }\end{array}$ & $\begin{array}{c}\text {-Well-educated } \\
\text { parents [+] } \\
\text { - High-status } \\
\text { parental job [+] } \\
\text { - Teacher training } \\
{[\text { Mix] }} \\
\end{array}$ & & & \\
\hline Household & $\begin{array}{l}\text { - Wealth [+] } \\
\text {-Edu. Expenditure }[+] \\
\text { - Poverty status [-] }\end{array}$ & $\begin{array}{c}\text { - Head of } \\
\text { household } \\
\text { education }[+] \\
\text { - Parent education } \\
{[+]}\end{array}$ & $\begin{array}{l}\text { - Association }[+] \\
\text { - Trust }[0] \\
\text { - Reciprocity }[+] \text {. }\end{array}$ & $\begin{array}{c}\text { - Access to mass- } \\
\text { media }[+]\end{array}$ & \\
\hline $\begin{array}{l}\text { Interactions: } \\
\text { 1. within level } \\
\text { cross resource }\end{array}$ & \multicolumn{5}{|c|}{ - Parent wealth * Reciprocity [- for highest income and + for lowest income] } \\
\hline $\begin{array}{l}\text { 2. between level } \\
\text { single resource }\end{array}$ & \multicolumn{5}{|c|}{$\begin{array}{c}\text { - Madrasah (mostly served poor children) * Municipality with high poverty rate }[-] \\
\text { - Urbanization * social capital (community association) }[+] \\
\text { - Urbanization * social capital (community reciprocity) }[-]\end{array}$} \\
\hline $\begin{array}{l}\text { 3. between level } \\
\text { cross resource }\end{array}$ & \multicolumn{5}{|c|}{ - Household social capital (association) * community social capital (trust) [+] } \\
\hline
\end{tabular}


Overall, our multilevels multi-resources framework and the related findings lead to the following conclusions. First, our findings are in line with the resource-based approach (Barney, 1991) that stipulates that diverse resources at different levels affect educational outcomes. As our multilevel analyses show, economic, physical, human, social and political capital at different levels affect unequal access to and quality of education.

Second, the presence of more resources available across levels helps improve educational outcomes. However, these resources affect inequality in educational outcomes differently and sometimes they even each other out. For instance, municipality education expenditure significantly reduces dropout rates, but it does not significantly decrease children's likelihood of never attending school. Living in an urbanized area significantly amplifies the effect of community associations on preschool participation, but it significantly reduces the effects of community reciprocity on preschool participation.

Third, next to well-known economic and human capital resources at the household level, such as parents' income and educational background, this paper shows that also political resources at the national level - through the implementation of a decentralized education system - contribute to education outcomes. Furthermore, at the organizational level, ideological and organizational differences in private Islamic schools (represented by the different streams and tracks) influence student achievement and achievement gaps.

Fourth, our study presented three types of interplay between levels and types of resources that can contribute to or help remedy inequality in access to and quality of education in Indonesia. For instance, within level cross-resource effects showed that reciprocity at the household level can buffer deficiencies in economic resources in relation to preschool participation. Between level single resource effects showed that the effect of association on preschool participation becomes stronger if the household lives in a community with high trust. In addition, higher investments in teaching time and teacher quality in the Integrationist schools can narrow student achievement gaps, which reflect between levels and cross resource effects.

\section{Methodological Implications}

Unlike in developed countries, data on inequality in access to and quality of education in Indonesia is still limited and scattered across institutions. Other data challenges relate to missing data as well as differences in labels and inconsistency in data coding. In our study, we handled these challenges by merging different data sources and linking the data in terms of different types of resources and levels. We also identified for what time period each data source is available and whether the variables and periods are comparable. Furthermore, we conducted some interviews and did data confirmation checks with the leaders of education organizations to verify our own coding and categorizations.

Linking, merging and confirming these different sources enabled us to simultaneously investigate the effects of various types of resources across different levels on inequality of access to and quality of education. Multilevel analyses allowed us to study variations in each level and to identify interplays within and between levels.

A limitation of our study is that it had to rely on (repeated) cross-sectional data. As a result, we cannot draw conclusions about the causal relations linking resources and inequality in educational outcomes. Future research might benefit from conducting longitudinal studies with more fine-grained variables, such as comparing students' achievement before entering school, and after one and two years of learning at different types of schools. Such research designs would allow a more detailed reconstruction of the social mechanisms linking the availability or lack of resources to educational decision making at the level of the household, and its collective level outcomes. Finally, with this study being limited to a single country, the findings cannot be generalized to other countries. Nevertheless, the framework and findings may be useful for comparative studies addressing countries with similar geographical and infrastructural challenges. 


\section{Practical Implications}

Education empowers people, and persistent inequality in educational systems and outcomes are a major concern in most countries. Our study provides some insight into potential points of departure for addressing inequality in access and quality of education in the Indonesian context. This study corroborates results of previous studies, according to which difference in resources affects variations in educational outcomes (see e.g. Suharti, 2013; Suryadarma, 2010; Newhouse and Beegle, 2006). Our results provide at least two important new understandings of practical relevance.

Firstly, the strong positive effects of household wealth and parents' educational level suggest that deficiencies in financial and human capital keep children out of school. Therefore, one could consider the use of direct financial support as well as other direct interventions, to help children living in poor households, in particular female-headed households. Government interventions may need to shift gradually from providing institutional support at the national or regional level to lower level institutions, such as municipalities and schools, or even directly to households and children, or to apply solutions at both institutional and individual levels simultaneously.

Secondly, it has long been contended that allocating resources to public education expenditures, such as teachers, classrooms, materials and others, is an important instrument to reduce inequality in educational outcomes (see e.g. Zhang and Kanbur, 2003; Sylwester, 2002). In addition to public education investments, our findings suggest that social capital can contribute to improve preschool participation and reduce unequal access to education. Therefore, common policy interventions to remedy inequality by removing school fees for compulsory education, increasing government investments, providing incentives for low-income and underprivileged groups, and supporting education quality and efficiency (UNESCO, 2009), can benefit from incorporating social capital as an additional resource in both household and community levels.

Thirdly, given that this paper mainly focused on the decentralized education system in Indonesia, its results tap into debates about how to define the role of the central, provincial, and municipal levels in handling educational service delivery with the aim of reducing regional discrepancies. Our study shows that government attention, from a national perspective, seems especially needed to improve schooling in rural areas and less developed municipalities.

Lastly, our results indicate that government attempts to improve Islamic private schools (since they perform less well than public schools) can best be focused on the traditionalist and modernist streams. Both streams predominantly serve children from low SES parents, and are thus associated with limited parental resources, leading in turn to inadequate school incomes. In addition, the presence of modernist schools in all provinces and almost all municipalities indicates that they reach diverse groups of students across the country, including remote areas where public schools do not exist. Therefore, improving the quality of modernist and traditionalist schools could lead to improved quality of learning for underprivileged and underserved students.

Overall, we found that municipal-level variation in educational inequality increased after decentralization. This suggests that policy makers need to realize that a "one size fits all policy" is difficult to apply in such diverse contexts. Consequently, it is recommended that policy makers, before implementing new policies and measures, take their time to carefully consider the contextual conditions in which these policies might work well and less well. 


\section{References}

Afrianto (2008). Reformulation of national examination policy in Indonesia. http://adsindonesia or.id/alumni/ASAC2008Papers/Afrianto-paper.pdf accessed on 30 August 2016.

Alderman, H. (2006). Improving Nutrition through Community Growth Promotion: Longitudinal Study of the Nutrition and Early Child Development Program in Uganda. Development Research Group, World Bank. Washington, D.C.

Allensworth, E.M. (2005). Dropout rates after high-stakes testing in elementary school: A study of the contradictory effects of chicago sports to end social promotion. Educational Evaluation and Policy Analysis 27(4), 341-364.

Al-Samarrai, S. (2013). Local Governance and Education Performance : A Survey of the Quality of Local Education governance in 50 Indonesian Districts, World Bank Other Operational Studies 16765, The World Bank.

Anderson, D.M. (2010). In school and out of trouble? The minimum dropout age and juvenile crime. University of Washington.

Arina, S.N. (2011). The effect of change in compulsory education on affecting birth weight. Tilburg University 2011.

Arunatilake, N. (2006). Education participation in Sri Lanka: Why all are not in school. International Journal of Educational Research, 45 (3): 137-152.

Badan Perencanaan Pembangunan Nasional (Bappenas). (2015). Data dasar pendidikan.

Barnett, W.S., \& Yarosz, D. (2007). Who goes to preschool and why does it matter? Preschool Policy Matters, Issue 15. New Brunswick: Rutgers, The State University of New Jersey, National Institute for Early Education Research.

Barney, J.B. (1991). Firm resources and sustained competitive advantage. Journal of Management, Vol.17, No.1, pp.99-120.

Barro, R. J., Lee J.W. (2001). International data on educational attainment updates and implications. Oxford Economic Papers 53 (3): 541-63.

Beard, V.A. (2005). Individual determinants of participation in community development in Indonesia. Environment and Planning C: Government and Policy 23:21-39.

Becker, G.S. (1993). Human capital: A theoretical and empirical analysis with special reference to education. University of Chicago Press.

Bernardo, A.B.I., Ganotice, F.A., \& King, R.B. (2015). Motivation gap and achievement gap

between public and private high schools in the Philippines. The Asia-Pacific Education Researcher 24: 657. doi:10.1007/s40299-014-0213-2

Blau, F. D. \& L. M. Kahn. (2005). Do cognitive test scores explain higher US wage inequality? Review of Economics and Statistics 87, 184-193.

Braun, H., Jenkins, F., \& Grigg, W. (2006). Comparing private schools and public schools using hierarchical linear modeling (NCES 2006 - 461). U.S. department of education, National Centre for Education Statistics, Institute of Education Science. Washington, DC: U.S. Government Printing Office. Nces.ed.gov/nationsreportcard/pdf studies/2006

Breen, R., Luijkx, R., Müller, W. \& Pollak, R. (2009). Nonpersistent inequality in educational attainment: evidence from eight European countries, American Journal of Sociology 114: 1475-521.

Central Bureau Statistics (CBS) of the Republic of Indonesia. (2005). National social economic survey 2005.

(2009). National socio-economic Survey 2009.

(2010). National social economic Survey 2010.

National social economic survey 1996-1999 and 2007-2011.

Central Bureau Statistics (CBS) of the Republic of Indonesia. (2011). Potential village 2011.

Colclough, C., Rose, P., \& Tembon, M. (2000). Gender inequalities in primary schooling: the roles of poverty and adverse cultural practice. International Journal of Educational Development, 20: 5-27.

Davis-Kean, E. P. (2005). The influence of parent education and family income on child achievement: The indirect role of parental expectations and the home environment. Journal of Family Psychology, 19(2), 294-304.

Fatchiati, N. (2015). Dinamika Ujian Akhir dari masa ke masa. Kompas, 15 April 2015. 
Galab, S., Vennam, U., Komanduri, A., Benny, L. \& Georgiadis, A. (2013). The impact of parental aspirations on private school enrolment: Evidence from Andhra Pradesh, India. Young Lives: Oxford.

Galiani, S. \& Schargrodsky, E. (2002). Evaluating the impact of school decentralization on education quality. Economia, vol. 2 (2), p.275-314.

Gangl, M. (2002). Changing labor market and early career outcomes: Labour market entry in Europe over the past decade. Work Employment Society 16(1), 67-90.

Habibi, N., Huang, C., Miranda, D., Murillo, V., Ranis, G., Sarkar, M. (2001). Decentralization in Argentina. Economic Growth. Center Discussion Paper 825, Yale University.

Hanushek, Eric A. (2007). Education production functions. Palgrave Encyclopedia. Hoover Institution, Stanford University .

Hasan, A., Hyson, M. \& Chang, M.C. (eds.). (2013). Providing and evaluating services for low income young children. The World Bank.

Heredia-Ortiz, E. (2007). The Impact of education decentralization on education output: A cross-country study. George State University: Economics Dissertations Paper 21.

Knight, J., \& Song L. (2000). Differences in educational access in rural China. Working paper, Department of Economics, University of Oxford.

Kristiansen, S., \& Pratikno. (2006). Decentralising education in Indonesia. International Journal of Educational Development 26, p.513-531.

Lundine, J., Hadikusumah, R.Y., Sudrajat, T. (2013). Indonesia's Progress on the 2015 MDGs. Strategic Review. pp.54-66. September 2013. Vol.3. Number 3. Jakarta:The Indonesian Journal of Leardership, Policy, and World Affairs.

Lynch, K., \& Baker, J. (2005). Equality in education. An equality of condition perspective. Theory and Research in Education, 3 (2), 131-164.

McNeal, R.B. (1999). Parental involvement as social capital: Differential effectiveness on science achievement, truancy, and dropping out. Social Forces, 78,117-144.

Merton, R.K. (1968). Social theory and social structure. Enlarged Edition. New York: The Free Press.

Ministry of Development of Disadvantaged Regions (MDDR). (2011). http://www.kpdt.go.id hal/300027/183-kab-daerah-tertinggal. Accessed 27 February 2014.

Ministry of Finance (MoF). (2012). Budget statistics. Jakarta.

Ministry of Home Affair (MoHA). (2012). http://otda.kemendagri.go.id/images/file/data_dob jumlah\%20daerah\%20otonom\%20baru\%202013.pdf. Accessed 27 February 2014.

Ministry of Education and Culture (MoEC). (2000). Data pokok pendidikan 1999/2000 dan perkembangan sejak 1994/1995 (termasuk madrasah). Jakarta: Balitbang Depdiknas.

-----. (2009). Buku panduan Bantuan Operasional Sekolah (BOS) untuk pendidikan gratis dalam rangka Wajib Belajar 9 tahun yang bermutu.

(2009). Peraturan Menteri Pendidikan Nasional no 75 tahun 2009 http://www.depdiknas go.id accessed on 30 August 2016.

(2010). Data pokok pendidikan.

----. (2013). Kebijakan dan program pendidikan menengah tahun 2013.

(2013). Micro-data of the national examination of the junior secondary school.

Mladovsky, P. (2014). Social capital and enrolment in community-based health insurance in Senegal. PhD thesis, The London School of Economics and Political Science (LSE).

Newhouse, David \& Beegle, Kathleen. (2006). The effect of school type on academic achievement: Evidence from Indonesia, Journal of Human Resources, University of Winconsin Press, vol 41(3).

OECD (2012), Equity and Quality in Education: Supporting Disadvantaged Students and Schools, OECD Publishing. http://dx.doi.org/10.1787/9789264130852-en

Paqueo, V., \& Sparrow, R. (2005). Free Basic Education in Indonesia: Policy scenarios and implications for school enrolment. World Bank. Jakarta.

Pfeffer, F. T. (2008). Persistent inequality in educational attainment and its institutional context. European Sociological Review, 24(5): 543-565.

Pong, S.L., \& Ju, D.B. (2000). The effects of change in family structure and income on dropping out of middle and high school. Journal of Family Issues, 21,147-169.

Pradhan, M., Brinkman, S.A., Beatty, A., Maika, A., Satriawan, E., de Ree, J., \& Hasan, A. 
(2013). Evaluating a community-based early childhood education and development program in Indonesia: study protocol for a pragmatic cluster randomized controlled trial with supplementary matched control group. Trials,14(1), 259. doi:10.1186/1745 6215-14-259.

Republic of Indonesia (1993). Lampiran Pidato Pertanggungjawaban Presiden/Mandataris Majelis Permusyawaratan Rakyat Republik Indonesia (MPR RI) di depan Sidang Umum MPR RI. 1 Maret 1993.

Roberts, K. (2009). Opportunity structures then and now. Journal of Education and Work Vol. 22, No. 5, November 2009, 355-368.

Robison, L.J., Schmid, A.A., \& Siles, M.E. (2002). Is social capital really capital? Review of Social Economy, 60: 1-21.

Rumberger, R.W. \& Larson, K.A. (1998). Student mobility and the increased risk of high school drop out. American Journal of Education, 107, 1-35.

Saraswati, E. (2012). Public spending education and inequality: A case study in Indonesia. International Journal of Social Science and Humanity, Vol. 2, No. 5, September 2012.

Self \& Grabowski. (2008). Examining the link between Japan's development and education of females. Pacific Economic Review 13/3, p. 279-288.

Shahnaz, L., \& Naeem, S. (2012). Why children never attend school in Pakistan? Evidence from PSLM 2010-11.

Shavit, Y. \& Blossfeld, H.P. (eds.). (1993). Persistent inequality: Changing educational attainment in Thirteen Countries. Boulder: Westview Press.

Shindler, J. (2010). Characteristics of out-of-school children of compulsory school age in South Africa: What the community survey 2007. A 'Consortium for Research on Educational Access, Transitions and Equity (CREATE) working paper.

Simatupang, R.R. (2009). Evaluation of decentralization outcomes in Indonesia: Analysis of Health and Education Sectors. Economics Dissertations.

Smith, M.H., L.J. Beaulieu, \& A. Seraphine. (1995). Social capital, place of residence, and college attendance. Rural Sociology 60:363-80.

Song, L. \& Lin, N. (2009). Social capital and health inequality: Evidence from Taiwan. Journal of Health and Social Behavior 50(2): 149-63.

Sparrow, R. (2007). Protecting education for the poor in times of crisis: An evaluation of a scholarship program in Indonesia. Oxford Bulletin of Economics and Statistics 69(1), 2007, 99-122.

Suharti. (2013). Trends in education Indonesia in D. Suryadarma \& G.W. Jones (Eds) Education in Indonesia. Singapore: Institute of Southeast Asian Studies (ISEAS).

Sumarto, S., Suryahadi, A. \& Widyanti, W. (2002). Designs and implementation of the Indonesian social safety net programmes. Developing Economies, 40(1), pp. 3-31.

Suliman, E.A., \& El-Kogali, S.E. (2010). Why are the children out of school? Factors affecting children's education in Egypt.

Suryadarma, D. (2010). The Muslim disparity in education attainment: Explanations from Indonesia. Arndt-Corden Department of Economics Crawford School of Economics and Government Australian National University.

Sylwester, K. (2002). Can education expenditures reduce income inequality? Economics of Education Review 21 (2002) 43-52.

Teachman, J.D., Paasch, K., \& Carver, K. (1996). School capital and dropping out of school. Journal of Marriage and the Family, 58, 773-783.

Tim Penyusun Lintas Kementrian dan Lembaga. (2007). Pedoman umum Program Keluarga Harapan (General guidelines of Household Conditional Cash Transfer 2007). Jakarta.

Treisman, D. (2000). Decentralization and the quality of government. Unpublished paper. www polisci.ucla.edu/faculty/treisman/. Accessed 27 February 2014.

United Nations Children's Fund (UNICEF) (2015). The investment case for education and equity. Education Section, Programme Division: New York.

United Nations Educational, Scientific and Cultural Organization (UNESCO) (2009). Education Indicators: Technical guidelines. Institute for Statistics.

Usman, S. (2001). Indonesia's decentralized policy: Initial experiences and emerging problems Paper presented at the European Southeast Asian Studies Conference, London: SOAS, September. 
Wenger, J. (2002). Does the dropout age matter? How mandatory schooling laws impact high school completion and school choice. Public Finance and Management 2(4), 507 543.

Wernerfelt, B. (1984). The resource-based view of the firm. Strategic Management Journal. 5 (2): $171-180$.

White, M.J. \& Kaufman, G. (1997). Language usage, social capital, and school completion among immigrants and native-born ethnic groups. Social Science Quarterly 78(2): 386-398.

Yuniarti, S.L. \& Hakim, L. (2014). The cabinet: Whither early childhood education? in http:/ www.thejakartapost.com/news/2014/11/05/the-cabinet-whither-early-childhood education.html\#sthash.5D6kXXrC.dpuf

Zhang, X \& Kanbur, R. (2003). Spatial inequality in education and health care in China.

http://www.bps.go.id/ accessed 27 February 2013.

http://www.bps.go.id/linkTabelStatis/view/id/1525 retrieved 12 March 2014.

http://www.djpk.depkeu.go.id retrieved 10 December 2013.

http://data.worldbank.org/indicator/SE.PRE.ENRR accessed 7 November 2015.

https://unnes.ac.id/berita/diapresiasi-publik-raeni-peroleh-tawaran-beasiswa-s2-ke-inggris/ accessed on 31 August 2016. 